\title{
An Egyptian Scholar at the Petrie Museum of Egyptian Archaeology
}

Ahmed M. Mekawy Ouda ${ }^{1, *}$

How to cite: Ouda, A. M. M. 'An Egyptian Scholar at the Petrie Museum of Egyptian Archaeology'. Papers from the Institute of Archaeology, 2019, 28(1): pp. 1-7. DOI: 10.14324/111.2041-9015.004

Published: 18/06/2019

\section{Peer Review:}

This article has been peer reviewed through the journal's standard double-blind review.

\section{Copyright:}

(c) 2019, The Author(s). This is an Open Access article distributed under the terms of the Creative Commons Attribution License (CC-BY) $4.0 \mathrm{https}: / /$ creativecommons.org/licenses/by/4.0/, which permits unrestricted use, distribution and reproduction in any medium, provided the original author and source are credited • DOI: [https://doi.org/10.14324/111.2041-9015.004].

\section{Open Access:}

Papers from the Institute of Archaeology is a peer-reviewed open access journal. 


\section{An Egyptian scholar at the Petrie Museum of Egyptian Archaeology}

Ahmed M. Mekawy Ouda

\section{Background}

In 2010, after I arrived in London to complete my $\mathrm{PhD}$ studies at the Institute of Archaeology UCL, my attention was drawn to a great man, the first professor of Egyptology in the United Kingdom (Drower 1985: 200-201; Drower 2004: 88), W. F. Petrie (1853-1942). The friends and employees of the Petrie Museum and staff at the Institute of Archaeology praise Petrie for his magnificent work and excavations in Egypt and Palestine. Through the Friends of the Petrie Museum (PMF) of Egyptian Archaeology, workshops, talks and festivals of art and pottery are held to commemorate the work of Petrie. Attendance is not restricted to British students and the doors of the Museum are open to all nationalities, encouraging public engagement.

\section{Initial Impression and Visit to the Museum}

The Petrie Museum keeps over 80,000 Egyptian objects and is the only museum in the United Kingdom which is called 'Museum of Egyptian Archaeology'. I was lucky enough to visit the Museum from time to time as my PhD supervisor was Professor Stephen Quirke, then curator of the Petrie Museum of Egyptian Archaeology (1999-2013). All of our meetings were held at the Museum and I used to look around the Museum before or after these meetings. Whilst I was exploring the Museum soon after my arrival, I found an object on display, UC16639 (Figure 1), which was not published. There was no available documentation for the date of acquisition, excavator or provenance of the object. This attracted my attention and it bears the name 'Werethekau', which inspired my PhD thesis entitled 'Werethekau 'Great of Magic' in the religious landscape of ancient Egypt' (Ouda 2014). 


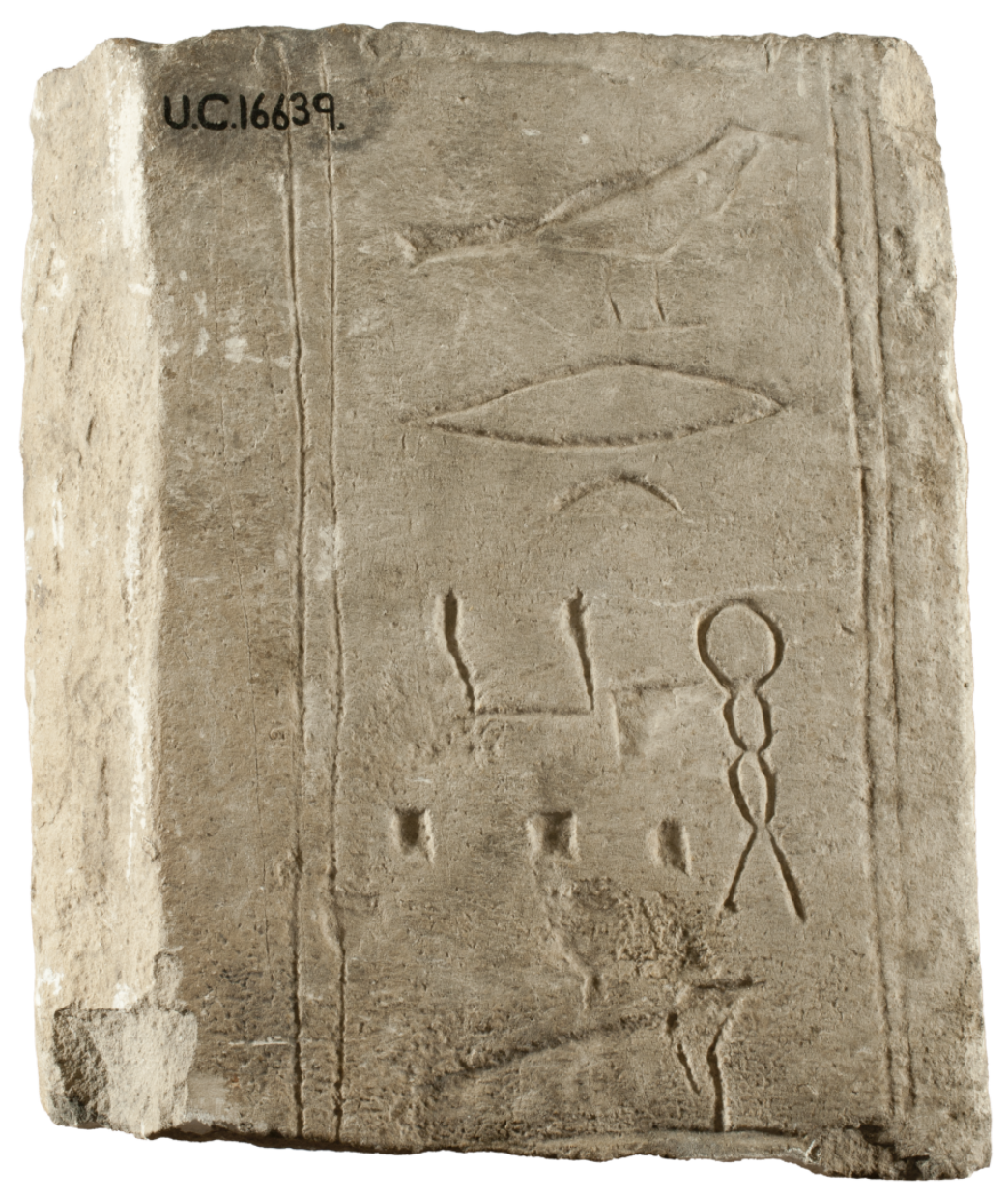

Figure 1: A block of stone with the name of Werethekau.

The initial report on this object was presented in the 'Graduate Student Conference' in February 2012. It was the first academic talk I delivered in the United Kingdom. I remember that the Room no. 612 at the Institute of Archaeology was filled to capacity by a very appreciative audience. In March that same year, I presented the talk again to the audience of Current Research in Egyptology XIII at Birmingham University (Heffernan et al. 2013). I finally published my findings in Papers from the Institute of Archaeology in 2013 (Ouda 2013: 1-7). 


\section{Organization of Various Events at the Museum}

I attended many talks and events from 2010-2014, which were organized by the Museum and the Friends of Petrie Museum, but I focus here on the events and talks which I did organize or teach.

\section{Teaching}

At the festival of art in May 2013 at the Petrie Museum, teaching children and adults how to write their names in Hieroglyphs (Figure 2). It was great to take part in this event as an Egyptian, teaching the language of his ancestors to foreigners from the United Kingdom, the States, Netherlands, Canada, Singapore, and Spain! While I was teaching in the study room, another Egyptian friend, Gamal Ibrahim, was teaching in another room on how to manufacture papyrus. Every child or adult, who wrote his/her name in hieroglyphs or manufactured papyrus, took something home with them as a memento of their day. This open event proved to be a wonderful occasion for all.

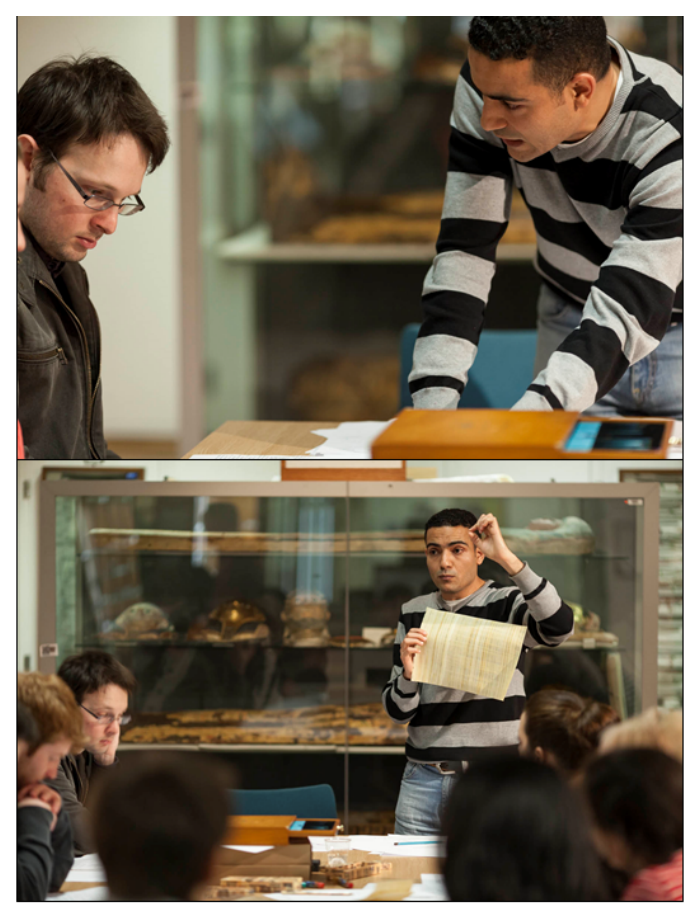

Figure 2: Ahmed M. Mekawy Ouda takes part in teaching on the occasion of 'the festival of art' at the Petrie Museum of Egyptian Archaeology. 


\section{Sharing the Museum and meeting new people}

The door of the Museum was open to me again when I led a group of Arab PhD students (Emad Ghandourah, Essam Banoqitah, Mansour Almurayshid, Khalild Aloufi) through the Petrie Museum from the Engineering Department at UCL. It was also an honour to lead the delegates of the Current Research in Egyptology XV 2014 in a tour to the Museum with my colleague, Lucia Gahlin, Chair of the Friends of the Petrie Museum. In July 2012, Stephen Quirke invited me to meet some Egyptian scholars taking part in the International Training Programme (ITP) at the British Museum. They visited the Petrie Museum (The British Museum 2012: 17), and we discussed the way the objects were displayed, the documentation system, and the use of audio-visual technology at the Museum. Among the group were Nevine Nizar Zakaria (GEM), Marwa Badr el Din (Egyptian Museum Cairo), Abdel Rehim Hanafy Mousa (Museum of Islamic Art) (The British Museum 2012: 20) and Mohamed Naguib (inspector and ceramicist at Abydos). I remember M. Naguib did not like the fact that 'many pottery jars were inserted in a small display case and they do not have enough space to be shown'.

\section{The Egyptian revolution}

The Petrie Museum was the perfect place to celebrate the first anniversary of the Egyptian revolution dated $25^{\text {th }}$ of January 2011. I participated in organizing this celebration together with curator Stephen Quirke and Debbie Challis, the audience development officer. We showed two short videos on the Egyptian revolution, and a famous song, ya el-Midan 'O (Tahrir) Square'. I made a comment on one of these videos (Figure 3) which was well received (Stevenson and Challis 2015: 23) and the event overall was a great success. Stephen Quirke and I hosted Soraya Morayef, an Egyptian writer and journalist, delivering a presentation on 'History Rewritten: Ancient Egyptian Art revived through post-revolutionary graffiti in Cairo' in May 2013 (Stevenson and Challis 2015: 23). The talk focused on introducing images of street art in Egypt after the revolution. The idea of continuity was indicated, linking modern Egypt to ancient Egypt as the images from ancient Egypt inspired modern street artists. 


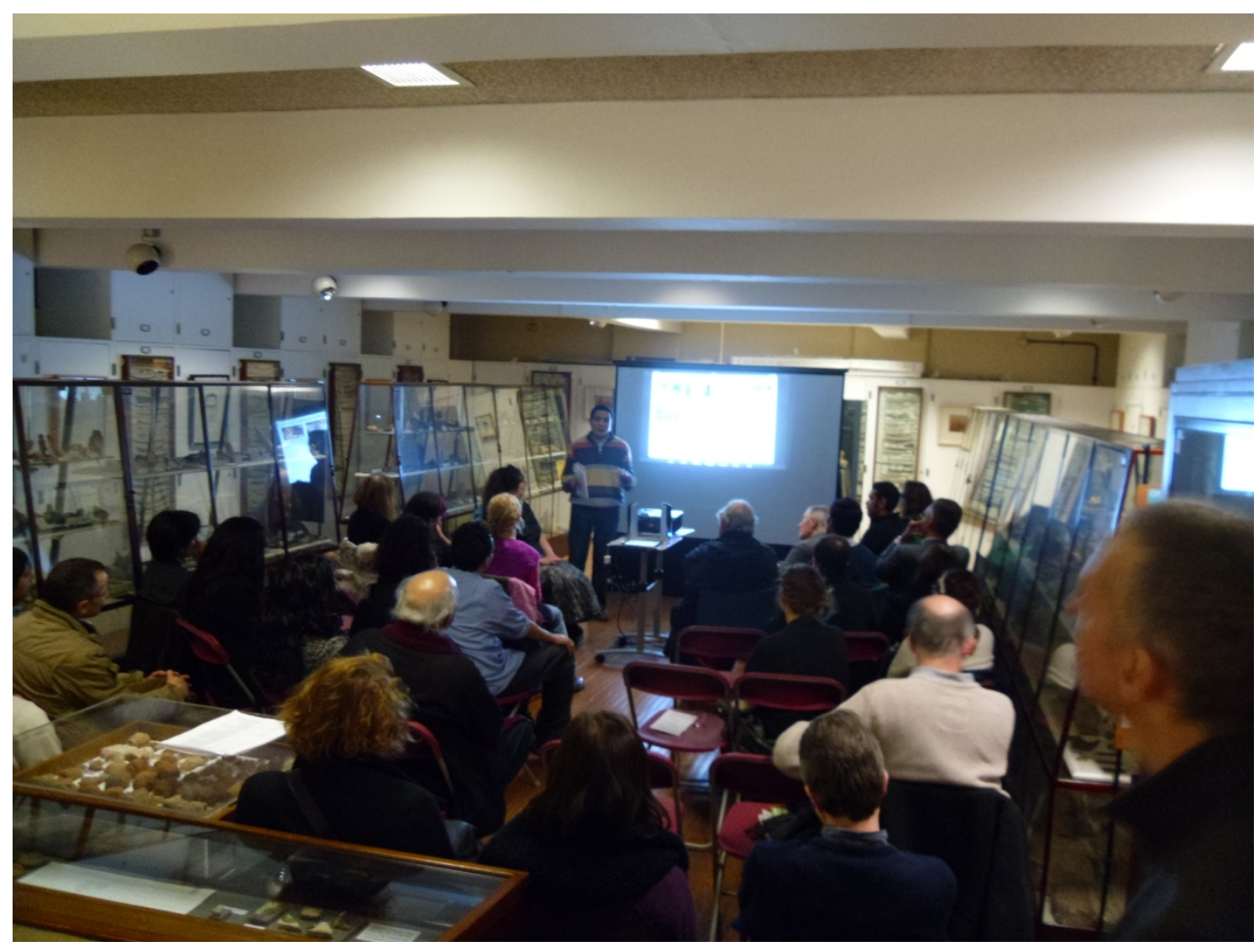

Figure 3: The celebration with the anniversary of the Egyptian revolution in 2012 at the Petrie Museum.

\section{The Museum and Continuous Research Inspiration}

When I got back from London to Egypt, I thought about the Egyptians who wrote on ancient Egypt, whether they are Egyptologists or non-Egyptologists, inspiring the acclaim of Petrie by the surrounding community in London. My first talk on "Ancient Egypt in the Writings of Ahmed Lutfi el-Sayed", which I delivered to EES Cairo in October 2014, was a result of this inspiration. I also delivered this talk to the delegates of Current Research in Egyptology XVI at Oxford University in 2015 (Alvarez et al. 2016: viii), the Free University Berlin in April 2017 and Humboldt University in May 2017. I received an invitation from my colleague Lucia Gahlin, Chair of the Friends of the Petrie Museum, to deliver a talk to the friends of Petrie who were touring Egypt in October 2016. I delivered this talk for them at Meridien Pyramids (Figure 4).

My relationship with the Petrie Museum continues. I have reported many varied objects, including the shabtis of the vizier Paser (Ouda 2016), the shabtis of the god's father Panebmontu (Ouda 2017: 2019), inscribed mud brick of the royal cup-bearer Tja-wy, 
Sarenenutet (Ouda 2015:359-365, figs. 1-4), and the Middle Kingdom oyster shells (Ouda 2019: 2020).

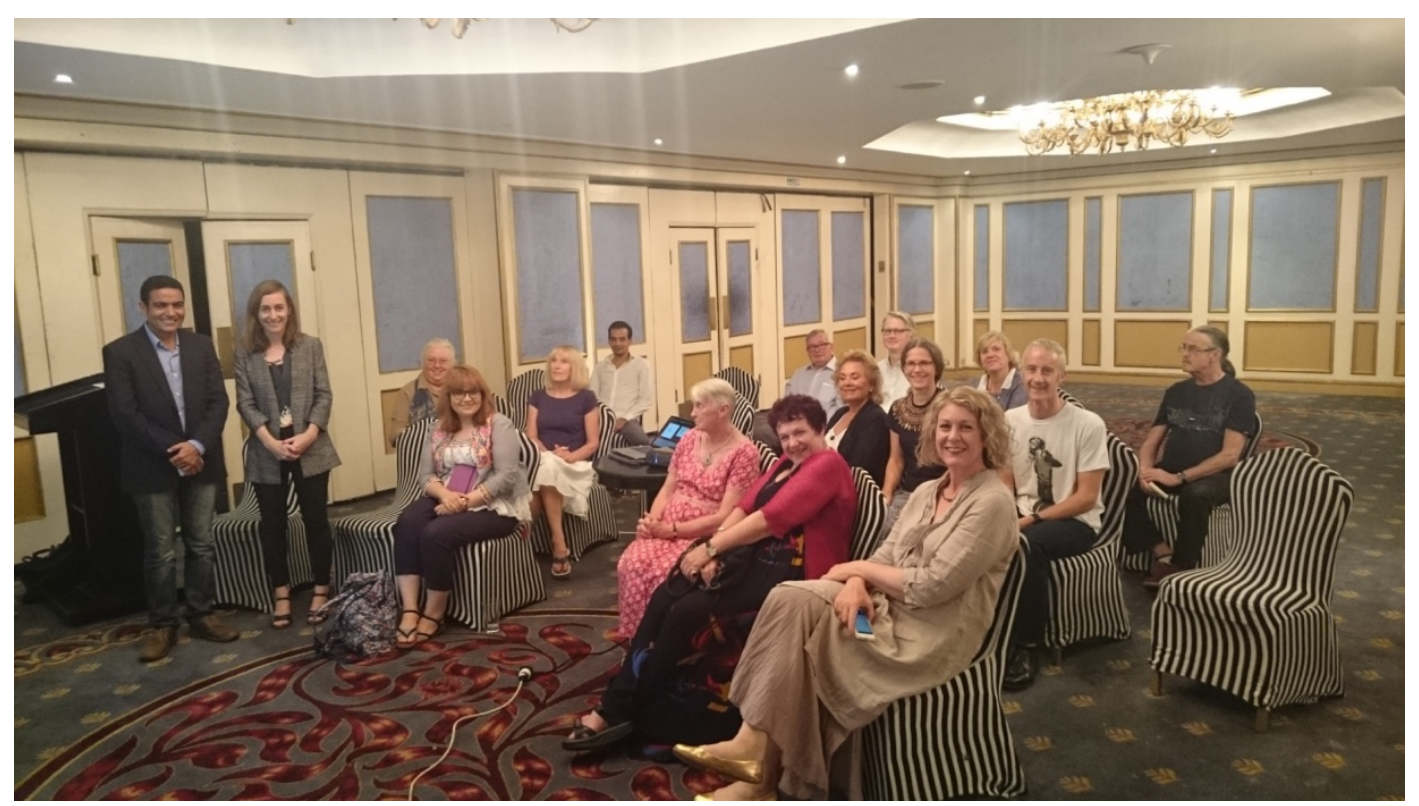

Figure 4: Ahmed M. Mekawy Ouda with friends of Petrie Museum at Meridian Cairo.

\section{Conclusion}

The Petrie Museum of Egyptian Archaeology was open to me, as it is open to many other nationalities. The Museum is small in size, but it runs great activities in relation to ancient and modern Egypt and shows the continuity of Egyptian history. There, I learnt what it means to have public engagement.

Acknowledgements: The author would like to thank the Senior Editors of PIA and the anonymous reviewers for their comments and suggestions.

\section{REFERENCES}

Alvarez, C, Belekdanian, A, Gill, A-K, Klein, S (eds.) 2016 Current Research in Egyptology 15: Proceedings of the Sixteenth Annual Symposium: University of Oxford, United Kingdom, 15-18 April 2015. Oxford: Oxbow books.

Drower, M, 1985 Flinders Petrie: A life in Archaeology. London: Victor Gollancz LTD. 
Drower, M 2004 Letters from the Desert: the Correspondence of Flinders and Hilda Petrie. Oxford: Oxbow books.

Heffernan, G, McGarrity, L, Graves, C, Millward, E, Bealby, M S (eds.) 2013 Current Research in Egyptology 13: Proceedings of the Thirteenth Annual Symposium University of Birmingham 2012. Oxford: Oxbow Books.

Ouda, A M M 2013 Who or what is Werethekau 'Great of Magic'? A problematic inscription (UC16639). Papers from the Institute of Archaeology 23 (1): 8, 1-7. Website: http://www.pia-journal.co.uk/article/view/pia.424 [accessed 28/07/2013].

Ouda, A M M 2014 Werethekau 'Great of Magic' in the religious landscape of ancient Egypt, PhD Thesis, UCL, London.

Ouda, A M M 2015 New Light on SA-Rnnwtt, TAwy, 'the Royal Cup Bearer' (UC 69964), Journal of Egyptian Archaeology 101, 359-365.

Ouda, A M M 2016 Three Shabtis of the Vizier Paser (UC39724-39726). The Journal of the American Research Center in Egypt 52, 303-320.

Ouda, A M M 2017 The Shabtis of the 'God's Father', Panebmontu. Mitteilungen des Deutschen Archäologischen Instituts Abteilung Kairo 73, 169-175.

Ouda, A M M 2019 Further Remarks on the Shabtis of the 'God's Father', Panebmontu. Göttinger Miszellen 257, 145-152.

Ouda, A M M 2019 (in press). Two inscribed Middle Kingdom oyster shells from Esna: reconstructing their archaeological context. Chronique d'Egypte 94/187.

Ouda, A M M 2020 (in press). Egyptian Middle Kingdom Oyster Shells with Royal Names: Function, Chronology and Gender Issues. Bulletin de l'Institut français d'archéologie orientale 119.

Stevenson, A and Challis, D 2015 Introduction: a modest little museum. In: A. Stevenson (ed.), The Petrie Museum of Egyptian Archaeology Characters and Collections. London: UCL Press, 11-26.

The British Museum 2012 International Training Programme 2012, London: the trustees of the British Museum.

https://www.britishmuseum.org/pdf/ITP\%20Report\%202012.pdf (accessed November 2018).

Figures: All figures provided by the author unless otherwise stated. 